\title{
A comparative cross-sectional study on the prevalence and morbidity of schistosomiasis in a community in northeastern Brazil (1979-2010)
}

\author{
Eric Vinaud de Melo', Walfredo da Costa ${ }^{2}$, Maria José Conceição ${ }^{1}$, José Rodrigues Coura1/+ \\ 'Laboratório de Doenças Parasitárias, Instituto Oswaldo Cruz-Fiocruz, Rio de Janeiro, RJ, Brasil \\ ${ }^{2}$ Núcleo de Medicina Tropical, Universidade Federal da Paraíba, João Pessoa, PB, Brasil
}

\begin{abstract}
A cross-sectional study on the prevalence and morbidity of schistosomiasis was conducted in the main settlement of the municipality of Alhandra, in the southern coastal region of the state of Paraiba, in 2010. The results of this study were compared with the results of a previous study conducted in the same area in 1979. The systematic sampling per family conglomerate included approximately $10 \%$ of the resident population in the urban area of Alhandra. Faecal examinations were performed using the Kato-Katz method. The clinical forms of the disease were classified in accordance with FS Barbosa as Type I - intestinal form, Type II - hepatointestinal form and Type III - hepatosplenic form. The prevalence of the infection in 2010 was 10.05\%, whereas in 1979 it was $46.6 \%$ among untreated patients. The percentages of the three clinical forms in 2010 were as follows: $95.3 \%$ Type I, 4.6\% Type II and 0\% Type III; in 1979, the percentages were $94.4 \%, 3 \%$ and $2.6 \%$ for Types I, II and III, respectively. In 1979, $6.07 \%$ of the Biomphalaria glabrata specimens (the intermediate host in this area) excreted cercariae, where in 2010 only 1.27\% of the specimens caught excreted the parasite.
\end{abstract}

Key words: schistosomiasis mansoni - cross-sectional studies - prevalence and morbidity - Alhandra - northeastern Brazil

The World Health Organization (WHO) has estimated that more than 200 million people in Africa, Asia, Latin America and the Caribbean have schistosomiasis and that more than 700 million people are exposed to infection in these three continental regions. Among the infected individuals, WHO estimates that at least $10 \%$ present the severe form of the disease and that $50-60 \%$ of them (i.e., more than 100 million people) present clinical manifestations of the disease, which represents an important worldwide public health issue (WHO 2011).

According to the Brazilian Ministry of Health, schistosomiasis caused by Schistosoma mansoni affects between 2.5-6 million people and more than 25 million are exposed to the risk of infection in Brazil (MS 2011). The range of this estimate, from 2.5-6 million infected people, indicates that the information on the prevalence of the disease includes substantial uncertainties. Since 2004, when Coura and Amaral published an epidemiological and control evaluation of schistosomiasis in endemic areas of Brazil covering the period from 1977-2002, few overall assessment studies have been conducted in this country. More recently, Conceição and Coura (2012) conducted a broad review on the epidemiology of schistosomiasis mansoni in Brazil. This review analysed the sources of infection and of the spread of the disease across Brazilian territory, Brazilian authors' contributions, the specific

doi: 10.1590/0074-0276130353

Financial support: $\mathrm{CNPq}$

+ Corresponding author: coura@ioc.fiocruz.br

Received 5 July 2013

Accepted 27 December 2013 treatment for the disease and the problems involved in this treatment. In summary, the transmission of schistosomiasis can be considered to occur over a vast endemic area in Brazil: from Maranhão to Minas Gerais (MG), especially in Paraíba (PB), Pernambuco (PE), Alagoas, Sergipe (SE), Bahia (BA) and MG, with foci in Pará, Piauí, Goiás, Distrito Federal, Rio de Janeiro, São Paulo, Paraná, Santa Catarina and Rio Grande do Sul (Coura \& Amaral 2004, Conceição \& Coura 2012).

Studies conducted by Coura et al. (1983, 1984, 1987, 1992), Coura and Amaral (2004) and Conceição and Coura (2012) have demonstrated the prevalence and morbidity of schistosomiasis in various areas of Brazil. In a hospital study, Coura et al. (1982) showed that of 4,652 patients, $12.82 \%$ had the hepatosplenic form (Type III) and $87.18 \%$ presented the hepatointestinal form (Type II). In a study in four field areas, two in MG (Capitão Andrade and Padre Paraíso), one in SE (Riachuelo) and another in PB (Alhandra), Coura et al. (1983) determined the prevalence of infection by $S$. mansoni through faecal examination (Kato-Katz). The prevalence of infection was $60.8 \%$ for patients in Capitão Andrade, $63.1 \%$ in Padre Paraíso, $50.5 \%$ in Riachuelo and $46.6 \%$ in Alhandra. Of these patients, 5.8\%, 4.4\%, 2.4\% and 2.4\%, respectively, showed the hepatosplenic form of the disease (Type III). Sarvel et al. (2011) evaluated a 25-year program for the control of schistosomiasis mansoni an endemic area in $\mathrm{MG}$ and showed a substantial reduction of prevalence, from $70.4 \%$ in 1981 to $1.7 \%$ in 2005 . The prevalence of the hepatosplenic form decreased from $7-1.3 \%$ during the same period.

\section{PATIENTS, MATERIALS AND METHODS}

This study represents a comparative analysis of the prevalence and morbidity of schistosomiasis caused by S. mansoni in Alhandra, on the southern coast of $\mathrm{PB}$ 
(Fig. 1), based on data obtained in 1979 and 2010 for the master's degree dissertations of Mendonça (1982) and de Melo (2012), respectively. Thus, the present study aimed to analyse the observed differences in the disease and their probable causes in that area over this 31-year period.

A register of the resident population in the urban area of the municipality of Alhandra was produced and systematic sampling per family conglomerate was applied. As the sample comprised one in every 10 inhabited houses, it covered approximately $10 \%$ of the resident population. The homes sampled were marked on a map of the area and were evaluated for their sanitary conditions, water supply, sewage disposal, type of sanitary facilities, type and quality of home, number of residents, number of rooms, location and distance from possible sources of infection (rivers, lakes or wells). Individual habits, such as river bathing, laundering and fishing were evaluated with a questionnaire.

The sample population was interviewed and clinically examined after these individuals had given their informed consent. The study project had previously been granted approval by the Ethical Committee for Research on Human Beings of the University Hospital of the Federal University of Paraíba. The anamnesis and clinical examination were oriented towards clinical manifestations of schistosomiasis, previous pathological history, previous diagnosis of schistosomiasis, clinical and surgical treatments performed, general clinical examination, liver and spleen palpation and other data of importance for the research, such as intercurrent diseases and alcoholism.

After evaluation of the social, epidemiological and clinical conditions of the sampled population, the prevalence of the infection was investigated through faecal
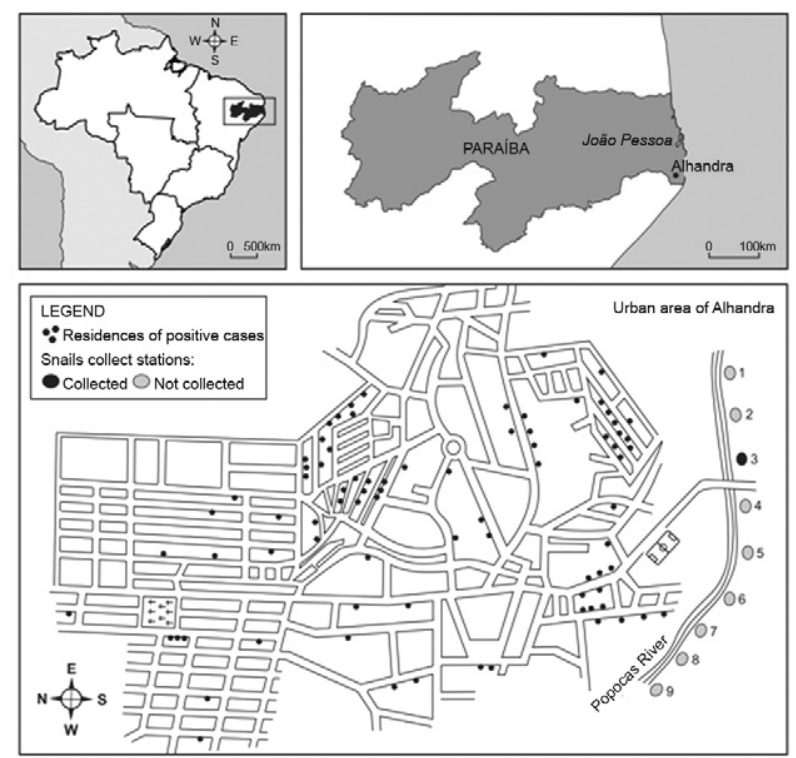

Fig. 1: location of Alhandra, state of Paraíba, Brazil, showing the main settlement of the municipally with the residences of positive case for Schistosoma mansoni and the Popocas River with the snails collect stations. examination using the Kato method, as modified by Katz et al. (1972). Properly identified plastic containers were distributed to each individual and the collection procedure for faeces was explained. Each day for three consecutive days, the receptacles containing the faecal samples were collected from each household that still had samples to be submitted. One sample of faeces was collected from each person. Two slides were prepared from each sample. Each slide were examined by two different technicians and reviewed by the author (EVM).

The patients who were positive for schistosomiasis were examined by one of the authors (WC) and were classified as follows regarding morbidity in accordance with the classification system of Barbosa (1966): Type I intestinal form, examination of faeces positive with nonpalpable liver and spleen, Type II - hepatointestinal form, palpable liver and non-palpable spleen, measured from the liver in relation to the right costal margin, and Type III - hepatosplenic form, palpable liver and spleen in relation to the right and left costal margin, respectively.

The Popocas River, which borders the main settlement of the municipality of Alhandra, is the primary and the closest source of infection by $S$. mansoni. Given that the population uses this river and wells derived from it for bathing, laundering, fishing and other activities, nine capture sites for the planorbid intermediate host of S. mansoni were chosen in this area (Fig. 2). Two capture periods were planned: the rainy season, from MaySeptember and the dry season, from October-December. The capture sites and derived wells were surveyed every two months during both seasons in accordance with the recommendations of the WHO. When molluscs were found, they were counted and classified and were subjected to a process to induce elimination of cercariae. The elimination rates were also evaluated. A random sample of molluscs was placed in boxes covered with moist gauze and was forwarded to the Malacology Laboratory of the Oswaldo Cruz Institute, for confirmation of the species classification and emergence of cercariae. The procedures for accessing, collecting and evaluating the infected snails were the same in 1979 and 2010.

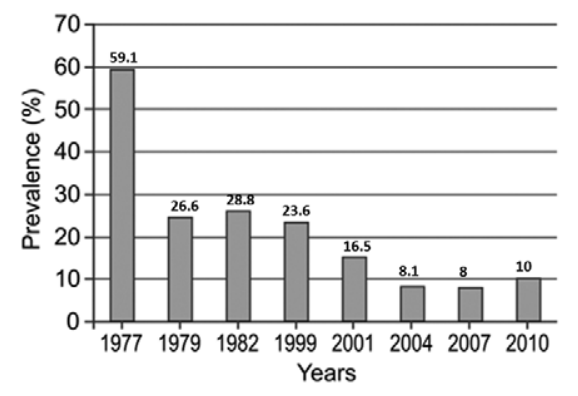

Fig. 2: sharp decrease the prevalence of schistosomiasis in Alhandra, state of Paraíba, Brazil, from 1977-1979, mainly due to mass treatment from the Special Program of Schistosomiasis Control and gradually decrease of prevalence from 1982-2010 due to successive treatments and to sanitation improvements. 


\section{RESULTS}

A total of 310 households were registered, with a total population of 1,260 people and an average of four inhabitants per household. In comparing the studies, it was observed that in $1979,82.2 \%$ of the houses were made of mud, $15.3 \%$ of brick and $2.5 \%$ of wood, whereas in 2010 , $20.1 \%$ were made of mud, $79.4 \%$ of brick and $0.44 \%$ of wood. In addition, $99.5 \%$ of the households had electricity. In $2010,90.5 \%$ of the households had water supplied through the public network by the state company Water and Sewage Company of Paraíba, although only $71.4 \%$ had proper treatment. In 1979, 66.9\% of the people used water directly from the Popocas River and 33.1\% used water from wells. These results show that a significant improvement had been made in the water sources used by the households. An overwhelming majority of the households in Alhandra in 2010 had deep sinks for doing laundry because they now had a water supply. In $1979,40.8 \%$ of the households of Alhandra had cesspits, whereas $59.8 \%$ of the waste was abandoned in the open air. In $2010,94.3 \%$ had cesspits and $5.6 \%$ of the waste was abandoned in the open air. Only $0.3 \%$ of the households had sewage collection, compared with $0 \%$ in 1979. In 2010 , the garbage from $76.6 \%$ of the households was collected by a public company, $10.8 \%$ was burned or buried and $12.6 \%$ was abandoned, whereas in 1979 only $15.4 \%$ was collected, $11.2 \%$ was burned or buried and $73.4 \%$ was abandoned in the open air.

Of the 1,260 people in the sample, 796 provided material for stool testing. Thus, $32 \%$ did not undergo the examination because of refusal or failure to provide material. However, the distribution of the 310 households did not alter the representativeness of the resident population of Alhandra. At the time of the most recent census, the population of the municipality was 11,146 . Thus, the sample of 796 people represented $7.14 \%$ of the resident population. Among the 796 people who underwent the stool test, 80 $(10 \%)$ eliminated eggs of $S$. mansoni. The parasite load was considered to be low, with a median ranging from 48-72 eggs per gram (epg) of faeces (Table I). Comparatively, the prevalence of schistosomiasis in Alhandra in 1979 was much higher reaching a mean of $46.6 \%$ and the parasite load was 231 epg of faeces in 302 patients untreated at the time of the survey. In 613 patients who had been treated during the six months prior to the study, the mean prevalence was $13.3 \%$ and the parasite load was 108 epg of faeces (Table II). The prevalence of schistosomiasis decreased markedly from 1977-1979 due to mass treatment by the Special Program of Schistosomiasis Control. A progressive decrease from $28.8 \%$ in 1982 to $10 \%$ in 2010 occurred due to improved sanitation and the treatment of positive cases by the Regional Management of Health Services of the State of Paraíba (Fig. 2).

During the rainy season of 2010, no molluscs were found in the surveys conducted at the nine sites along the Popocas River or in the wells surveyed. At the end of the rainy season, in September-October 2010, 244 molluscs were captured at only one site, Station 3, on the Popocas River. Of these molluscs, 87 were dead, 157 were alive and only two $(1.27 \%)$ were eliminating cercariae. This result is of great importance in terms of the reduction of the prevalence of morbidity due to $S$. mansoni infection in the area. In 1979, Mendonça found that $6.07 \%$ of the molluscs were infected, the prevalence of $S$. mansoni infection was $46.6 \%$ among 302 untreated individuals and $2.4 \%$ of those infected had hepatosplenic forms (Type III), with a mean elimination of 231 epg of faeces (Mendonça 1982). Table II shows the total number of people examined per age group, the numbers and percentages of treated and untreated positive patients and the median numbers of $S$. mansoni eggs in the treated and untreated groups in 1979 .

\section{DISCUSSION}

The control of schistosomiasis is one of the most difficult tasks facing public health services in affected countries owing to the worldwide spread of the intermediate host, its mechanisms of escape from existing control methods, the frequency of human contact with water, the dynamics of schistosome transmission, the lack of sanitation and clean water supplies for human populations and the limitations of individual and mass treatment. Furthermore, the control of schistosomiasis using combined measures is very expensive and, to be effective, must be maintained over the mid to long term (Coura 1995).

After the discovery by da Silva (1908) of schistosomiasis caused by $S$. mansoni in BA, the first studies conducted in northeastern Brazil on this disease and its vectors were those of Lutz $(1916,1919)$ and Lutz and Penna (1918). During the 1920s, Maciel (1924, 1925, 1930) conducted several studies on the disease and its treatment at the Naval Hospital of Recife. These studies were complemented by Jasen (1946), using treatment as prophylaxis for schistosomiasis among sugar cane workers at the Catende Plant, PE and by da Silva (1949, 1957). Fieldwork on the epidemiology of schistosomiasis and its prophylaxis in northeastern Brazil began with Pessoa and Barros (1953), Pessoa et al. (1955), Pessoa and Amorim (1957), including research in PB. These studies were continued by Barbosa $(1966,1968)$ in PE and consolidated in BA by Prata and Schroeder (1967), Prata and Bina

\section{TABLE I}

Number of persons by age group examined, number and percentage of positives for Schistosoma mansoni and its egg load median, Alhandra, state of Paraíba, Brazil 2010

\begin{tabular}{lccc}
\hline $\begin{array}{l}\text { Age groups } \\
\text { (years) }\end{array}$ & $\begin{array}{c}\text { Examined } \\
(\mathrm{n})\end{array}$ & $\begin{array}{c}\text { Positives } \\
\mathrm{n}(\%)\end{array}$ & $\begin{array}{c}\text { Egg } \\
\text { load }^{a}\end{array}$ \\
\hline $0-10$ & 180 & $13(7.2)$ & 48 \\
$11-20$ & 197 & $20(10.1)$ & 72 \\
$21-30$ & 116 & $10(8.6)$ & 48 \\
$31-40$ & 84 & $10(11.9)$ & 48 \\
$41-50$ & 74 & $10(13.5)$ & 48 \\
$>50$ & 145 & $17(11.7)$ & 72 \\
\hline Total & 796 & $80(10)$ & 56 \\
\hline
\end{tabular}

$a$ : median, egg/g/faeces. 
TABLE II

Number of persons by age groups examine, number and percentage of positives for Schistosoma mansoni, treated and untreated and its egg load median, Alhandra, state of Paraíba, Brazil 1979

\begin{tabular}{|c|c|c|c|c|c|c|c|}
\hline \multirow[b]{2}{*}{$\begin{array}{l}\text { Age groups } \\
\text { (years) }\end{array}$} & \multirow[b]{2}{*}{$\begin{array}{l}\text { Examined } \\
\text { (n) }\end{array}$} & \multicolumn{3}{|c|}{ Previous treated } & \multicolumn{3}{|c|}{ Untreated } \\
\hline & & $\begin{array}{c}\text { Examined } \\
\mathrm{n}(\%)\end{array}$ & $\begin{array}{c}\text { Positives } \\
\text { n (\%) }\end{array}$ & Egg load ${ }^{a}$ & $\begin{array}{c}\text { Examined } \\
\mathrm{n}(\%)\end{array}$ & $\begin{array}{c}\text { Positives } \\
\text { n (\%) }\end{array}$ & Egg load ${ }^{a}$ \\
\hline $0-10$ & 354 & $245(69.2)$ & $19(23.2)$ & 84 & $109(36)$ & $13(9.2)$ & 132 \\
\hline $11-20$ & 205 & $157(76.6)$ & $28(34.1)$ & 120 & 48 (15.9) & $30(21.3)$ & 174 \\
\hline $21-30$ & 106 & $65(61.3)$ & $15(18.3)$ & 144 & $41(13.6)$ & $32(22.7)$ & 408 \\
\hline $31-40$ & 75 & $48(16.6)$ & $8(9.7)$ & 84 & $27(8.9)$ & $19(13.8)$ & 276 \\
\hline $41-50$ & 69 & $47(17)$ & $8(9.7)$ & 108 & $22(7.3)$ & $11(7.8)$ & 180 \\
\hline$>50$ & 106 & $51(7.8)$ & $4(4.8)$ & 108 & $55(18.2)$ & $36(25.5)$ & 216 \\
\hline Total & 915 & $613(67)$ & $82(13.3)$ & 108 & $302(16.6)$ & $141(46.6)$ & 231 \\
\hline
\end{tabular}

a: median, egg/g/faeces.

(1968) and Bina and Prata (1983, 2003), using treatment as a form of controlling schistosomiasis in rural areas. Kloetzel $(1962,1963,1964)$ made an important contribution to studies on morbidity due to schistosomiasis and its relationship with the intensity of infection. More recently, the publication of the excellent book Schistosoma mansoni and esquistossomose, organised by Carvalho et al. (2008) and with contributions by 78 of the leading Brazilian experts on schistosomiasis, has presented a broad and comprehensive perspective on this disease.

Approaches to the control of schistosomiasis have involved the use of one or more of the following methods, either in isolation or in combination: (i) control of the intermediate host using molluscicides or biological methods, (ii) basic sanitation and clean water supply, (iii) health education and (iv) individual or mass treatment. None of these methods is capable, on its own, of exerting about effective control of schistosomiasis, except in populations of a very limited size or under very special conditions. Molluscicides are expensive and toxic and they have only a temporary effect. No effective biological control method is yet available. Basic sanitation and a clean water supply, combined with health education, potentially represent the most effective approach, but only in the mid to long term. Mass treatment reduces morbidity, but does not control transmission. The protection of individuals has proved to be impracticable on a large scale.

Coura and Camillo-Coura (1980) and Coura et al. $(1983,1984,1987,1992)$ conducted studies on the morbidity, evolution and control of schistosomiasis in areas of MG, SE and PB. Following the master's degree dissertations and PhD thesis of Conceição $(1976,1985)$ in Capitão Andrade, MG, and of Mendonça (1982) in Alhandra, PB, several studies were conducted by Conceição and Borges-Pereira (2002), Conceição et al. (2007) and Conceição and Coura (2012) on the prevalence of morbidity, evolution and the response to specific treatment of schistosomiasis in rural areas in $\mathrm{MG}$. In $\mathrm{PB}$, in addition to the study conducted by Mendonça (1982) in Alhandra, Coura et al. (1987) conducted an evaluation of the Schistosomiasis Control Program in all areas covered by the program in that state, including Alhandra. With the dissertation of de Melo (2012), which formed a basis for the present study, 33 years of observations of schistosomiasis have now been conducted in Alhandra. Before the activities of the Schistosomiasis Control Program began, Coura (1977) reviewed the data from the Health Diagnosis of the State of Paraíba. This analysis showed that the prevalence of schistosomiasis in Alhandra was 59.1\%, the highest of the 12 municipalities studied in that state. Due to mass treatment with oxamniquine (Machado 1982), the prevalence of schistosomiasis decreased markedly from 1979 onwards, as shown by Mendonça (1982). Since then, the prevalence of schistosomiasis has decreased gradually to $10 \%$ (Fig. 2) due to successive treatments and sanitary improvements, as shown in the present study.

\section{ACKNOWLEDGEMENTS}

To Heloisa Diniz, for the Figures of this paper, and to the Laboratory of Malacology of IOC/Fiocruz, for the classification of snail species and it cercariae positivity.

\section{REFERENCES}

Barbosa FS 1966. Morbidade da esquistossomose. Rev Bras Malar 1: 3-159.

Barbosa FS 1968. Esquistossomose mansônica: repercussões sobre a comunidade. Rev Soc Bras Med Trop 2: 153-156.

Bina JC, Prata A 1983. Regressão da hepatoesplenomegalia pelo tratamento específico da esquistossomose. Rev Soc Bras Med Trop 16: 213-218.

Bina JC, Prata A 2003. Esquistossomose na área hiperendêmica de Taquarandi. Infecção pelo Schistosoma mansoni e formas graves. Rev Soc Bras Med Trop 36: 2011-2016.

Carvalho OS, Coelho PZ, Lenzi HL 2008. Schistosoma mansoni e esquistossomose. Uma visão multidisciplinar, Fiocruz, Rio de Janeiro, 1123 pp. 
Conceição MJ 1976. Morbidade da esquistossomose mansoni em uma comunidade rural de Minas Gerais, MsD Thesis, Universidade Federal do Rio de Janeiro, Rio de Janeiro, 91 pp.

Conceição MJ 1985. Comportamento experimental de amostras de Schistosoma mansoni em relação às formas clínicas da esquistossomose, PhD Thesis, Universidade Federal do Rio de Janeiro, Rio de Janeiro, 109 pp.

Conceição MJ, Borges-Pereira J 2002. Influence of specific treatment on the morbidity of schistosomiasis mansoni in an endemic area of Minas Gerais, Brazil. Mem Inst Oswaldo Cruz 97: 755-757.

Conceição MJ, Borges-Pereira J, Coura JR 2007. A thirty years follow-up study on schistosomiasis mansoni in a community of Minas Gerais, Brazil. Mem Inst Oswaldo Cruz 102: 1007-1009.

Conceição MJ, Coura JR 2012. Epidemiology of schistosomiasis mansoni in Brazil. In MB Rokni (ed.), Schistosomiasis. Available from: cdn.intechweb.org/pdfs/25973.pdf.

Coura JR 1977. Diagnóstico de saúde do estado da Paraíba. Análise de dados publicados, Vol. I, UFRJ/UFPB, Rio de Janeiro, 73 pp.

Coura JR 1995. Control of schistosomiasis in Brazil: perspectives and proposals. Mem Inst Oswaldo Cruz 90: 257-260.

Coura JR, Amaral RS 2004. Epidemiologial and control aspects of schistosomiasis in Brazilian endemic areas. Mem Inst Oswaldo Cruz 99 (Suppl. I): 13-19.

Coura JR, Camillo-Coura L 1980. Perspectivas de controle da esquistossomose com especial referência ao tratamento em massa. Rev Soc Bras Med Trop 8: 153-158.

Coura JR, Conceição MJ, de Menezes AP, dos Santos ML, de Mendonça MZG 1983. Morbidade da esquistossomose mansoni no Brasil. II - Estudo em quatro áreas de campo nos estados de Minas Gerais, Sergipe e Paraíba. Mem Inst Oswaldo Cruz 78: 1-11.

Coura JR, Conceição MJ, dos Santos ML, de Mendonça ZG, Cutrim RNM 1992. Cross-sectional and evolutive studies of schistosomiasis mansoni in untreated and mass treated endemic areas in the Southeast and Northeast of Brazil. Mem Inst Oswaldo Cruz 87 (Suppl. IV): 175-182.

Coura JR, Conceição MJ, Pereira JB 1984. Morbidade da esquistossomose mansoni no Brasil. III. Estudo evolutivo em uma área endêmica no período de dez anos. Mem Inst Oswaldo Cruz 79: 447-453.

Coura JR, de Queiroz GC, Florêncio CG, Argento CA, Coutinho SG, Figueiredo N, Wanke B, Camillo-Coura L 1982. Morbidade da esquistossomose mansoni no Brasil. I - Estudo de 4.652 casos observados no Rio de Janeiro de 1960 a 1979. Mem Inst Oswaldo Cruz 77: 69-88.

Coura JR, Mendonça MZG, Madruga JP 1987. Tentativa de avaliação do Programa Especial de Controle da Esquistossomose (PECE) no estado da Paraíba, Brasil. Rev Soc Bras Med Trop 20: 67-76.

da Silva JR 1949. Estudo clínico da esquistossomose mansoni (doença de Manson Pirajá da Silva), Thesis, Universidade Federal do Rio de Janeiro, Rio de Janeiro, 452 pp.

da Silva JR 1957. Valor e importância do tratamento específico da esquistossomose mansoni no campo da profilaxia. Rev Bras Med 14: 524-526.

da Silva MAP 1908. Contribuição para o estudo da schistossomiase na Bahia. Bras Med 22: 281-283.

de Melo EV 2012. Estudo seccional comparativo de prevalência e morbidade da esquistossomose mansoni no municipio de Alhandra, estado da Paraiba (1979-2010), MsD Thesis, Instituto Oswaldo Cruz/Fiocruz, Rio de Janeiro, 66 pp.
Jansen G 1946. Profilaxia experimental da esquistossomose de Manson. Mem Inst Oswaldo Cruz 44: 549-578.

Katz N, Chaves A, Pellegrino J 1972. A simple device for quantitative stool thick - smear technique in schistosomiasis mansoni. Rev Inst Med Trop Sao Paulo 14: 397-400.

Kloetzel LK 1962. Aspectos epidemiológicos da esquistossomose mansônica em uma população de Pernambuco; suas correlações clínicas, PhD Thesis, Universidade de São Paulo, São Paulo, 119 pp.

Kloetzel LK 1963. Some quantitative aspect of diagnosis and epidemiology in schistosomiasis mansoni. Am J Trop Med Hyg 12: 334-347.

Kloetzel LK 1964. Natural history and prognosis of splenomegaly in schistosomiasis mansoni. Am J Trop Med Hyg 13: 541-544.

Lutz A 1916. Observações sobre a evolução do Schistosoma mansoni. Brazil Med 30: 385-387.

Lutz A 1919. O Schistosomum mansoni e a schistosomatose segundo observações feitas no Brasil pelo Dr Adolpho Lutz. Mem Inst Oswaldo Cruz 11: 121-155.

Lutz A, Penna O 1918. Estudos sobre schistosomatose feitos no norte do Brasil por uma comissão do Instituto Oswaldo Cruz. Relatório e notas de viagem apresentados pelos Drs Adolpho Lutz e Oswino Penna. Mem Inst Oswaldo Cruz 10: 83-94.

Machado PA 1982. The Brazilian program for schistosomiasis control, 1975-1979. Am J Trop Med Hyg 31: 76-86.

Maciel H 1924. Algumas notas em torno do tratamento da schistosomose intestinal. Sci Med 3: 3-24.

Maciel H 1925. Contribuição para o estudo da schistosomose intestinal, Imprensa Naval, Rio de Janeiro, 147 pp.

Maciel H 1930. Estudo clínico e terapêutico da esquistossomose intestinal, Thesis, Rio de Janeiro, 162 pp.

Mendonça MZG 1982. Estudo sobre a esquistossomose mansoni em Alhandra, no estado da Paraíba, MsD Thesis, Faculdade de Medicina, Universidade Federal do Rio de Janeiro, Rio de Janeiro, 78 pp.

MS - Ministério da Saúde Brasil 2011. Esquistossomose 2010. Available from: portal.saude.gov.br/portal/saude/profissiona/visualizar_texto.cfm?idtxt $=35752$.

Pessoa SB, Amorim JP 1957. Contribuição para a história natural da esquistossomose mansônica no Nordeste brasileiro e sugestões para sua profilaxia. Rev Bras Malar 9: 5.

Pessoa SB, Barros PR 1953. Notas sobre a epidemiologia da esquistossomose mansônica no estado de Sergipe. Rev Med Cir Sao Paulo 13: 147-154.

Pessoa SB, Silva LHP, Costa L 1955. Observações sobre a epidemiologia da esquistossomose no estado da Paraíba. Rev Bras Malar 7: 305-310.

Prata A, Bina JC 1968. Development of the hepatosplenic form of schistosomiasis (a study of 20 patients observed during 5 years period). Gaz Med Bahia 68: 49-60.

Prata A, Schroeder S 1967. A comparison of whites and negroes infected with Schistosoma mansoni in a hyperendemic area. Gaz Med Bahia 67: 93-98.

Sarvel AK, Oliveira AA, Lima AC, Katz N 2011. Evaluation of a 25year-program for the control of schistosomiasis mansoni in an endemic area in Brazil. PLoS Negl Trop Dis 5: e 990.

WHO - World Health Organization 2011. Schistosomiasis. Available from: who.int/schistosomiasis/en/. 